\title{
Download
}

UDC: 314.74 (477) https://doi.org/10.17721/2308-135X.2021.61.61-69

Lyubitseva Olha Olexandrivna, Doctor of Geographical Sciences, Professor Taras Shevchenko National University of Kyiv, Kyiv, Ukraine, e-mail: loa_13@ukr.net, ORCID ID: 0000-0002-8508-9395

Kochetkova Iryna Valentynivna, Candidate of Geographical Sciences, Associate Professor Taras Shevchenko National University of Kyiv, Kyiv, Ukraine, e-mail: kiv_univ@ukr.net, ORCID: 0000-0001-5342-7444

\section{EDUCATIONAL MIGRATION: UKRAINE IN THE SYSTEM OF GENERAL TRENDS}

Objectives of the article: to analyze the migration process in Ukraine in order to obtain education against the background of the global process in the educational sphere and the general migration process for compliance with general migration trends.

The research methodology is based on the processing of analytical and statistical materials from various sources, both national and foreign, using methods of analysis, synthesis, statistical processing of information.

Research results. It has been established that educational migrations are a dynamically developing process since the end of the twentieth century, to which more and more countries are joining. This trend is also inherent in Ukraine, where educational migration has been developing dynamically throughout the 21 st century. The factors influencing the external mobility of students are the military-political and economic crisis. Students go to study mainly to neighboring countries. Educational migration processes from Ukraine in their dynamics and geography correspond to the trends characteristic of labor migrations. The geography of 
educational migrations to Ukraine is also expanding and flows are increasing, although they are much smaller in volume than educational flows from Ukraine.

The scientific novelty of the research lies in the identification of correlations between the general trends of the migration process and educational migration.

The practical significance of the results obtained is aimed at drawing attention to the problem of the outflow of youth, which is the demographic, labor and intellectual potential of the nation, abroad.

Key words: migration process, educational migration, labor migration.

\section{References}

1. Brenzovych K. S. Mizhnarodna students $\square$ ka mihratsiya ta yiyi vplyv na sotsial no-ekonomichny rozvytok krayin [International student migration and its impact on socio-economic development of countries] / Kateryna Stepanivna Brenzovych, Yevheniya Pavlivna Nemesh // Economy and Society. - 2017. - №10. - pp. 32-36. Resource access mode: http://economyandsociety.in.ua/journal/10_rus/7.pdf

2. State Statistics Service of Ukraine [Electronic resource] - Access mode: http://www.ukrstat.gov.ua/ (access date 12.07.2021)

3. Yemelyanova Y. Ukrayins $\square$ ka osvitnya students $\square$ ka mihratsiya v konteksti hlobalizatsiynykh vyklykiv [Ukrainian educational student migration in the context of globalization challenges] / Y. Yemelyanova, A. Tereshchenko // Sociological studies. - 2020. - №2 (17). - pp. 6-12 DOI: 10.29038/2306-3971-2020-02-06-12

4. Ivanova I. F. Mizhnarodna osvitnya mihratsiya ukrayins $\square$ koyi molodi: prychyny, naslidky. [International educational migration of Ukrainian youth: causes, consequences.] / I. F. Ivanova. 
// Bulletin of Odessa National University. Sociology and Political Science. - 2017. - Toi 22. - №1 (28) - pp. 45-53.

5. Mihratsiya v Ukrayini. Tsyfry i fakty [Migration in Ukraine. Facts and Figures] - Kyiv: International Organization for Migration, 2019. - 19 p.

6. Ryul V.O. Doslidzhennya student-s $\square$ koyi mihratsiyi molodi na prykladi DVNZ «Uzhhorods $\square$ koho natsional $\square$ noho universytetu» [ Research of student migration of youth on the example of Uzhhorod National University]/ Viktoriya Oleksandrivna Ryul// Social work and problems of migration processes in the globalized world: Proceedings of the International scientific-practical conference (Chernivtsi, May 3-4, 2018) - Chernivtsi: Chernivtsi National University, 2018.- pp.215-221

7. Stepurina S. O. Tendentsiyi osvitn $\square$ oyi mihratsiyi ta yiyi vplyv na instytutsiyne seredovyshche $\checkmark$ Ukrayini [Tendencies of educational migration and its impact on the institutional environment in Ukraine] [Electronic resource] / S.O. Stepurina, V.I. Derikhovska // Economy and Society = Economy and Society: electron. Science. specialties type. - 2018. - № 17. - pp. 496-505. Access mode: http://www.economyandsociety.in.ua/journal/17_rus/73.pdf

8. Faisal M. L. Akademichna mobil $\square$ nist $\square$ ukrayins $\square$ kykh studentiv yak pokaznyk mihratsiynykh protsesiv $v$ Ukrayini [Academic mobility of Ukrainian students as an indicator of migration processes in Ukraine]/ Muts Luay Faisal // Investments: practice and experience. - 2019. - №3. pp. 118-122.

9. Szymanska K.V. Posylennya znachennya ekonomichnykh ta politykobezpekovykh determinant u formuvanni mihratsiynykh motyviv students $\square$ koyi molodi [Strengthening the importance of economic and politically secure determinants in the formation of migration motives of student youth] / K.V. Szymanska // Global and national problems of economics: electronic scientific professional publication. - 2017. - Issue 16. - pp. 86-91.

10. Banks M. Global student mobility / M. Banks, R. Bhandari // The SAGE handbook of international higher education, 2012. - pp. 379-397. 
11. Bista K. International student mobility: Examining trends and tensions/K. Bista, G. Sharma, U. Gaulee//International student mobility and opportunities for growth in the global marketplace, 2018.-pp. 1-14.

12. Choudaha R. Three waves of international student mobility (1999-2020) / Rahul Choudaha. // Studies in Higher Education. - 2017. - №42 (5). - pp. 825-832 https://doi.org/10.1080/03075079.2017.1293872

13. European Commission - Eurostat - Database [Electronic resource] - Access mode: https://ec.europa.eu/eurostat/data/database (access date 12.07.2021)

14. Facts and figures: Mobility in higher education. From the UNESCO Science Report, Towards 2030 [Electronic resource] - Access mode: https://en.unesco.org/node/252278 (Access 12.07.2021)

15. Gao H. China and International Student Mobility / H. Gao, H. de Wit. // International Higher Education. - 2017. - №90. - pp. 3-5 https://doi.org/10.6017/ihe.2017.90.9992

16. Glossary [Electronic resource] // The UNESCO Institute for Statistics (UIS) - Access mode: http://glossary.uis.unesco.org/glossary/en/home (Access 12.07.2021)

17. Glossary on Migration [Electronic resource] // International Organization for Migration. 2019. - Access mode: https://publications.iom.int/system/files/pdf/iml_34_glossary.pdf. (Access 12.07.2021)

18. International students [Electronic resource] // Migration data portal - Access mode: https://www.migrationdataportal.org/themes/international-students (Access 12.07.2021)

19. IOM's Global Migration Data Analysis Centre [Electronic resource] - Access mode: https://gmdac.iom.int/ 
(Access 12.07.2021)

20. Jóźwiak I. Crisis Driven Mobility between Ukraine and Poland. What Does Available Data (not) Tell Us? / I. Jóźwiak, M. Piechowska. // University of Warsaw, Centre of Migration Research (CMR). - 2017. - №99/157. - pp. 5-26.

21. King R. International student mobility literature review/R. King, A. Findlay, J. Ahrens., 2010. $-54 \mathrm{p}$.

22. L Waters J. Education, Internationalization of / Johanna L Waters // International Encyclopedia of Human Geography / Audrey Kobayashi., 2020. - (2). - pp. 77-83. https://doi.org/10.1016/B978-0-08-102295-5.10661-4

23. Pawłowski A. Eufunkcje i niemeterialne wartości turystyki międzynarodowej na pograniczu polsko-ukraińskim w aspekcie kształcenia kadr w dziedzinie turystyki [Eufunctions and non-metering values of international tourism in the Polish-Ukrainian borderland in terms of training staff in the field of tourism]/ Andrzej Pawłowski // Geography, Economics and Tourism: national and international experience // The Proceedings of the XV International Scientific Conference. - Lviv: Ivan Franko National University of Lviv Publishing Center, 2021. - 326 p. pp. 204-209

24. Rizvi F. Theorizing student mobility in an era of globalization / Fazal Rizvi. // Teachers and Teaching. - 2011. - №17 (6). - pp. 693-701. https://doi.org/10.1080/13540602.2011.625145

25. Teichler U. Internationalisation Trends in Higher Education and the Changing Role of International Student Mobility / Ulrich Teichler. // Journal of international Mobility. - 2017. - №1. - pp. 177-216 https://doi.org/10.3917/jim.005.0179

26. Wei $\mathrm{H}$. An empirical study on the determinants of international student mobility: a global perspective / Hao Wei. // Higher Education. - 2013. - №66. - pp. 105-122. 
https://doi.org/10.1007/s10734-012-9593-5

27. World migration report 2020 [Electronic resource] - Access mode:

https://publications.iom.int/system/files/pdf/wmr_2020.pdf (Access 12.07.2021)

28. Zhao Y. Globalization in Education / Yong Zhao // International Encyclopedia of the Social \& Behavioral Sciences / James D. Wright., 2015. - (2). - pp. 247-253.

https://doi.org/10.1016/B978-0-08-097086-8.92113-5 